\title{
Student Misbehavior: An Exploratory Study Based on Sri Lankan Secondary School Teachers' Perceptions
}

\author{
Kanchana. R. Menikdiwela. \\ Department of Counseling Psychology, Sri Lanka International Buddhist Academy (SIBA Campus), Pallekele, \\ Sri Lanka
}

\begin{abstract}
Student misbehavior is one of the most common problems affecting schools around the world. The main objectives of this study were to identify common and unacceptable misbehaviors of secondary school students and the reasons behind student misbehaviors from Sri Lankan teachers' point of view. A qualitative research study was conducted with twelve Sri Lankan secondary school teachers. The findings of the research study revealed that current secondary school students do not respect teachers, show more self-centered behaviors and engage in more problematic behaviors in school which are harmful for themselves as well as for the others, compared to the students that the teachers have taught and been with 10-15 years ago. A list of 17 student classroom misbehaviors and a list of 07 school based student misbehaviors were generated. The highly reported student classroom misbehaviors were disrespecting teachers, engaging in irrelevant tasks during lessons and verbal aggression. The highly reported school based misbehaviors were disrespecting school authority figures, unnecessary involvement with dangerous drugs and developing and supporting inappropriate and harmful relationships. The participants' responses on the reasons behind student misbehavior were simplified into five main sources: family, education system, teachers, students and society. The findings of the study will be useful to improve the Sri Lankan education system to create well behaving individuals to the society, as so far there has not been sufficient studies addressing this issue. The research study reveals that there is a great need for making some changes in the current education system to change the stressful atmosphere in schools and successfully promote students' physical, cognitive, personal, social, emotional, moral and spiritual development to reduce and prevent negative behavioral issues of students.
\end{abstract}

Keywords: student misbehavior, secondary school teachers, secondary school students, Sri Lanka

DOI: $10.7176 / \mathrm{JEP} / 11-17-12$

Publication date:June 30th 2020

\section{Introduction}

\subsection{Student Misbehavior and Its Effects}

Student misbehavior is one of the main problems in schools around the world today. Teachers identify student misbehavior decreases the effectiveness of teaching and learning processes and causes disturbance in the classroom. Dealing with these problematic behaviors in school or classroom is extremely time-consuming for teachers. It has been reported that teachers spend more time on issues of discipline and order in school or classroom than it is really needed (Willert,2017; Gregg, 1995; Little, 2005).

There are many terms that have been used in literature to define and explain problematic behaviors of students. Few of such terms are misbehavior, misconduct, disciplinary violations, disruptive behavior and problem behavior (Finn, Fish \& Scott, 2008; Thomson, 2009). There is no exact definition for student misbehavior. There has been some semantic debate over 'what compose of student misbehavior?' which has led to different definitions (Mohammad, Alireza \& Hasan,2013). For instance, Turnuklu \& Galton (2001) define student misbehavior as a type of behavior that hinders the flow of the academic performance. According to Charles (2008), the definition of misbehavior is "behavior that is considered inappropriate for the setting or situation in which it occurs". In addition, Kyriacou and Ortega (2010) define it as "any behavior by pupils which interferes with the smooth running of the lesson" (p. 415).

In fact, student misbehavior can negatively affect teachers (Rieg, Paquette, and Chen, 2007; Clunies-Ross, Little, and Kienhuis,2008; Kathryn,2010) and fellow students (Austin and Agar, 2005; Hwung, 2016). Furthermore, previous research has shown that students' misbehavior is highly related to low academic achievement and dropping out of school of misbehaving students (Hwung, 2016; Whisman \& Hammer,2014, Finn, Fish, \& Scott, 2008). It has been found out that student misbehavior is a major contributor to teacher stress, teacher burnout and their job dissatisfaction (Tsouloupas, Carson \& MacGregor, 2014; Aloe, Amo, \& Shanahan, 2014; Chang, 2013). It also forms an uncomfortable, insecure and a fearful environment at school that is experienced by both students and teachers in the same way (Mahasneh et al, 2012). A number of research studies have proved that classroom management is a major challenge not only for novice teachers but also for well experienced teachers, as a result of having to deal with student misbehavior in their classes (Koutrouba, 2013). 


\subsection{Types of Student Misbehavior}

Teachers observe lots of different types of problematic behaviors in a school or a classroom setting. There are mainly two types of student problematic behaviors: school-based problematic behaviors and classroom-based problematic behaviors (Dalgı̨̧ and Bayhan, 2014). Even though the problematic behaviors occur in school and classroom may seem to be different from each other, many research studies show that there is a strong correlation between these school-based and classroom-based behavior problems (Huizinga \& Jakob-Chien, 1998 in Dalgıç and Bayhan, 2014). That means, there is a possibility that those who engage in one form of these misbehaviors tend to engage in the other form of misbehavior as well. Conduct problems, substance use and crime are the most common school-based problem behaviors (Wilson, Gottfredson \& Najaka, 2001). A large number of research has been conducted focusing on different types of classroom misbehavior. Evertson, Emmer, and Worshan (2006) have classified classroom misbehavior into four categories:

1. no issue: these misbehaviors cannot be taken as serious issues considering the fact that they only take a short length of time and do not interrupt learning or direction. For example; short distractedness and a brief time of daydreaming.

2. minor issue: these misbehaviors are against the classroom principles or methods. If these practices do not occur regularly they do not really interfere with learning. For instance, getting out, eating something, or passing notes.

3. significant issue yet restricted in degree and impacts: for example, a student rarely finishes a given task, or may hit other students.

4. a raising or spreading issue: this is where a minor issue gets problematic and becomes a risk to the learning environment. For instance, many students often shout loudly and roam around the classroom (Çimen \& ÇepikKiriş, 2015).

Research on student classroom misbehaviors has found out that student behavioral problems in the classroom differ according to the class, lesson content, educational level of students, time, situation, student characteristics and the teacher's characteristics (Malak, Deppeler \& Sharma,2014; Tsouloupas, Carson \& Matthews, 2014).

\subsection{Reasons of Student Misbehavior}

Student misbehavior cannot be considered as an isolated factor even though it mainly occurs in the classroom or school setting. It needs to be analyzed in accordance with the whole environment of the student's life. When considering why students misbehave, according to Jessor and Jessor's (1977) problem behavior theory, an individual's personality aspects (motivation, beliefs, personal control) and his/her environmental aspects (parents and friends as models) act together to generate a set of conventional and problematic behaviors (Finn, Fish \& Scott, 2008). In addition, Yuan and Che (2012) pointed out most of the reasons behind student misbehavior can be simplified to three main sources: children, teachers, and society. Therefore, identifying the structure of the most frequent misbehaviors occur in school or classroom due to their correlations with each other and with other life experiences can provide clues on prevailing youth problem patterns. If someone wants to solve a problem, identifying the root of the problem is the key to the solution. In order to that, if the reasons for student misbehavior are better understood, "they will be in a better position to create conditions in which there is less need or fewer opportunities for such behavior" (Robertson, 1996 in Yuan and Che, 2012).

\subsection{The Importance of Identifying Teachers' Perceptions of Student Misbehavior}

Ding, Li, Li and Kulm (2008) pointed out that enhancing students' learning is not achievable only through effective pedagogy for presenting the content, but also effectiveness in respect of classroom management and dealing with misbehavior. Teachers must be effective in managing student misbehavior to create a positive learning environment for students. In order to make this happens, it is important to understand teachers' perceptions of students' misbehavior (Koutrouba, 2013). It is imperative to note that the meaning and nature of misbehavior change, according to the teacher's perception and interpretation of it (Turnuklu and Galton,2001). Teachers' perceptions of student behavior are likely to be influenced by the cultural context in which the behavior takes place (Malak, Deppeler and Sharma,2014). If understanding teachers' perceptions of student misbehavior is important to develop positive learning environments in schools, then, more cross cultural research studies must be carried out to identify their perceptions on student misbehavior. This is predominantly important when realizing that adolescent behavior has enormously changed with the advance in technology. It does not take so much time to popularize some misbehaviors in adolescents because of the internet (Sun \& Shek,2011).

Many studies have been conducted to examine the definitions, ranges of student misbehavior and causes based on teachers' perceptions in different cultural contexts. For example, Crawshaw's (2015) literature review on secondary school teachers' perceptions of student misbehavior which consisted of 20 studies conducted in different countries including Australia, China, Greece, Jordan, Malta, the United Kingdom and the United States from 1983 to 2013. The main conclusions of this review show that teachers perceived that talking out of turn and 
similar misbehaviors were the most frequent misbehaviors of the students. In addition, they have perceived stealing and vandalism as critical misbehaviors whilst pointing out more severe or potentially violent behaviors that have occurred not often.

When considering the Asian context, Dalgıç and Bayhan (2014) conducted a meta-analysis on student misbehaviors that affect classroom management. They reviewed the theses and published articles from 20002012 in Turkey on student misbehaviors from the perspectives of teachers. The results revealed that task avoidance, constant talking with classmates, verbal hostility towards peers and teachers, damaging school stuff, and coming late are the most frequent student misbehavior types mentioned by the teachers. Findings also showed a slight relationship between perceived student misbehavior and teachers' teaching field, teacher seniority, educational background of teachers, and the number of students in the classroom. In addition, Kyriacou's (2010) study on Japanese high school teachers' views of student misbehavior, has revealed that the most frequent misbehavior types comprised resting head on desk during the lesson, talking out of turn, arriving late for the lesson, using a mobile phone during the lesson and interrupting other students. Having emotional and/or behavioral difficulties was the first main reason and parents were the second major reason for student misbehavior in Japanese context. In the Chinese context, Sun and Shek's qualitative research study (2011) with 12 secondary school teachers revealed that the most common and disruptive problem behavior was talking out of turn, followed by non-attentiveness, daydreaming, and idleness. The most unacceptable problem behavior was disrespecting teachers with regard to disobedience and rudeness, followed by talking out of turn and verbal aggression.

All these studies indicate that teachers across different cultural contexts highly rate "talking out of turn" as the most frequent and troublesome student misbehavior.

When considering the Sri Lankan context, it seems that classroom misbehavior has not received considerable research attention yet. Consequently, the literature on students' behavioral issues in the Sri Lankan context is very limited. Although work may exist, the researcher could not find more research work located in a search of international databases (e.g. ERIC, Jstore, Scopus, Wiley library, and Google/Google Scholar) and national resources. The only related study the researcher could find was a study on child disciplinary methods practiced in Sri Lankan schools which was conducted by De Silva, Senarath, De Zoysa and Weerasinghe in 2018. The results revealed teachers highly use corporal punishment and psychological aggression to control student misbehaviors in schools. In addition, they found the most common reasons for punishments were noncompletion of homework, not adhering to the school dress code and love affairs.

Under these circumstances, it is essential to understand more about Sri Lankan teachers' perceptions of student misbehavior. In order to find effective interventions to improve students' misbehavior, this must be done first. Consequently, the present study aimed to examine misbehaviors among secondary school students in Sri Lanka based on the views of teachers. Practically, the findings of the study would be useful for educators, school administrators, school counselors, psychologists and teachers to develop more effective and culturally applicable strategies to manage misbehavior and improve students' behavior in the school context.

\section{Objectives of the study}

Based on the above considerations, the objectives of the study were to:

1. identify secondary school teachers' definition of student misbehavior.

2. generate a list of secondary school students' misbehaviors perceived by Sri Lankan school teachers.

3. identify misbehaviors that are perceived as the most common and disruptive to teaching and learning of students

4. identify and analyze whether there are any noticeable changes in current student misbehaviors compared to student misbehavior that happened in schools about $10-15$ years ago.

5. explore and analyze reasons of student misbehavior in schools.

\section{Methodology}

\subsection{Participants}

Twelve secondary school teachers (who teach grade 9-13 classes) were purposefully selected to the study from six government mix-sex schools (two teachers from one school) located in Katugasthota division in Kandy district. The sample was consisted of 5 males and 7 females. Five of them were members of the school discipline committee. The average of their teaching experience was 20.83 years (range $=10-30$ years).

\subsection{Research Design \& Method of Data Collection}

The qualitative research method was used in this study. Under which, semi-structured interview method was used to collect data. 


\subsection{Procedure}

Firstly, a pre-test was done with an individual who was similar to the sample in order to assess the validity/usefulness of the apparatus. After doing the pre-test, the researcher made sure that the semi-structured interview questionnaire was accurate and useful for the study. After that, twelve secondary school teachers were selected and interviewed. All the interviews were done on a one-to-one basis after making appointments with each participant. Each interview was conducted by the researcher of this study in Sinhala (the mother tongue of both the interviewer and interviewees). In addition, the interviews were recorded after getting permission from the participants. The duration of a single interview was within 1-1 1/2 hours. In the beginning, an explanation was given to all the participants regarding the purpose of conducting the study, the nature of the study and how the data would be used. Moreover, a proper assurance of the anonymity of their identity was emphasized. The interviews were conducted as informally as possible while encouraging the participants to talk freely despite the presence of the MP3 recorder.

Tools used:

A self - constructed, semi-structured interview guide was created focusing on the objectives of the study and based on a wide literature search on this topic.

3.4 Data Analysis

Thematic analysis was used to analyze the data.

\subsection{Findings}

4.1 Secondary School Teachers' Definition of Student Misbehavior

According to the main findings of the study, the majority of participants defined student misbehavior as any form of behavior that violates explicit rules or implicit norms of the school and classroom, interferes the classroom order and interrupts the smooth process of teaching and learning in the classroom or school. Only three out of twelve teachers added another point to the above definition of student misbehavior. That was, student misbehavior includes any form of negative behavior that is inappropriate to the student's chronological age.

Eg. Participant 06 - "I think, student misbehavior is any form of negative behavior which is not appropriate to the student's age, violates school or classroom rules and norms, interferes to maintain the order of classroom and the smooth process of teaching and learning in the classroom or school."

\subsection{Categories of Student Misbehavior}

Table 1 and Table 2 summarize the responses regarding students' classroom misbehaviors and school-based student misbehaviors reported by twelve secondary school teachers.

\subsubsection{Categories of Student Classroom Misbehaviors}

The responses on the types of student classroom misbehaviors were classified into 17 main categories, and 8 of them were further divided into subcategories. As presented in Table 1, the highly reported categories of student classroom misbehaviors were, "disrespecting teachers", "doing something in private which is unrelated to the lesson," "verbal aggression", "Making so much noise", "purposively disturbing classmates", "out of seat", "physical aggression", "talking out of turn", "on attentiveness/daydreaming/idleness," and "being unmotivated and showing lack of interest to study all the time".

All the respondents of the study highly emphasized that unlike students they have taught and seen 10-15 years ago, nowadays secondary school students do not respect teachers properly. They attempt to manipulate or dominate teachers, show disobedience and rudeness to teachers more often, talkback, humiliate teachers and try to get revenge from teachers when they give punishments to correct misbehaviors of students. In addition, four teachers reported that some students purposefully ignore teachers.

Participant 02 - "Unlike in the past, these students try to control us. It is hard to give advice to them. They talkback and directly show anger towards us. Also, if we give a small punishment to correct their problematic behavior, they even try to get revenge from us. One of my colleagues was attacked by a group of students recently. They do not follow the instructions immediately given by us like our past students. We have to instruct them so many times to get something done (ex: homework) by them, but still, some students do not listen to us at all."

In addition, teachers mentioned that the misbehavior of doing something private which is not relevant to the lesson is very disturbing to everybody in the class. Some students tear papers into small pieces, write and draw irrelevant things on papers while the lesson is being conducted.

Eg. Participant 01- "When we teach, some students are tearing papers. They don't even know why they do it. Also, some students draw pictures of naked women, flowers or just scribble something on a paper. Sometimes they write verses of songs, words or symbols and they only know the meaning of them."

All the teachers reported that some students deal with personal stuff like playing with pens, pencils and other items during the lesson. In addition, many participants of the study stated that passing irrelevant chits to 
classmates during the lesson is another annoying student misbehavior. For example, one teacher explained that he found a chit while teaching in his class which says "Can I send you a Sinhala one?". He somehow has found out that they were talking about a Sinhala porn video through that chit. Furthermore, the other two misbehaviors coming under this category include eating during the lesson and trying to get isolated without doing group work. Furthermore, the teachers explained that secondary school students exhibit verbal aggression in the classroom mainly through quarreling with classmates. In addition, sometimes they speak the foul language, tease classmates and do gossiping with others. "Making so much noise" was another highly mentioned classroom misbehavior of the participants. They explained that students try to make noise whenever they can by shouting, having an endless group chat with friends and singing in the classroom.

Participant 04 - "Students always try to make noise. If we go out of the class for a minute while teaching, then other classes can't work. They make such a big noise. Sometimes, they sing loudly by tapping on the desk with their pens and pencils. It is really disturbing to everybody".

Another highly reported problematic classroom behavior among secondary school students was purposefully disturbing classmates. Teachers stated that some students attempt to prevent others from learning by talking to them, nipping or poking to them, showing them irrelevant things to the lesson or interfering with their books, materials and equipment. According to the majority of participants, those who do not work properly in the classroom are envious towards bright or studious students. Such students attempt to interrupt motivated students' concentration on the lesson somehow. They laugh at or humiliate bright students when they respond to teachers' questions to demotivate them. Many teachers mentioned that even some bright students are envious of each other by having competitive mindsets.

Participant 05- "Today, students want to defeat others. They are so envious towards each other. Those who do not work properly always try to disturb others by doing various things during the lesson. They want to distract others' attention payed to the lesson somehow. Even some bright students, they are so envious to other bright students, because they think someone would score higher than them. They do not give their notebooks to anyone, even to their best friends who missed the class. They sometimes even try to harm the good name of their competitors by spreading bad rumors on them."

Moreover, students display their physical aggression mainly through attacking classmates and destroying the class property while fighting with classmates. The respondents highly emphasized that boys show more physical aggression compared to girls in the classroom.

The participants stated that students are mostly out of seats. They frequently wander around the classroom inappropriately and skip classes. They talk out of turn by having a disruptive conversation with the teacher and classmates during the lesson and asking totally irrelevant questions during the lesson.

Table 1:A summary of the teachers' perceptions of the types of student classroom misbehaviors

\begin{tabular}{|l|l|c|}
\hline Category & Subcategory & Number of responses \\
\hline \multirow{4}{*}{ Disrespecting teachers } & Attempt to manipulate or dominate teachers & 10 \\
& Disobedience/ refusing to carry out instructions & 11 \\
& Rudeness/talking back/ arguing with the teacher & 12 \\
& Humiliating/ offending teacher & 06 \\
& Try to get revenged from teachers & 10 \\
& Ignoring the teacher & 04 \\
\hline \multicolumn{1}{|c|}{ Something in } & Subtotal & $\mathbf{5 3}$ \\
\hline which is & Tearing papers into small papers & 08 \\
private & Irrelevant writing and drawing & 11 \\
unrelated to the lesson. & Dealing with personal stuff & 12 \\
& Passing chits which include irrelevant content to & 08 \\
& classmates & 04 \\
& Eating & 05 \\
\hline & Getting isolated from others & $\mathbf{4 8}$ \\
\hline Verbal aggression & Subtotal & 12 \\
& Quarreling with classmates & 10 \\
& Speaking foul language & 09 \\
& Teasing classmates & 08 \\
\hline & Gossiping & $\mathbf{3 9}$ \\
\hline Making so much noise & Subtotal & 11 \\
& Singing & 12 \\
& Shouting inappropriately & $\mathbf{3 4}$ \\
\hline & Constantly having group chats with friends & \\
\hline
\end{tabular}




\begin{tabular}{|c|c|c|}
\hline Category & Subcategory & Number of responses \\
\hline $\begin{array}{l}\text { Purposively disturbing } \\
\text { classmates }\end{array}$ & $\begin{array}{l}\text { Preventing others from learning by talking to them, } \\
\text { nipping or poking to them, showing them irrelevant things } \\
\text { to the lesson or interfering with their books, materials and } \\
\text { equipment. } \\
\text { Laugh at or humiliate bright students when they respond } \\
\text { to teachers' questions. } \\
\text { Being envious towards bright or studious students }\end{array}$ & 11 \\
\hline & Sub Total & 31 \\
\hline Out of seat & $\begin{array}{l}\text { Skipping Classes } \\
\text { Leaving the class constantly } \\
\text { Inappropriately wandering around the classroom }\end{array}$ & $\begin{array}{l}08 \\
06 \\
10\end{array}$ \\
\hline & Subtotal & 24 \\
\hline Physical aggression & $\begin{array}{l}\text { Attacking classmates } \\
\text { Destroying class property when fighting with classmates }\end{array}$ & $\begin{array}{l}12 \\
10\end{array}$ \\
\hline & Subtotal & 22 \\
\hline Talking out of turn & $\begin{array}{l}\text { Having disruptive conversations with teachers and } \\
\text { classmates during the lesson. } \\
\text { Asking totally irrelevant questions during the lesson }\end{array}$ & $\begin{array}{l}11 \\
09 \\
\end{array}$ \\
\hline & Subtotal & 19 \\
\hline $\begin{array}{l}\text { Non- attentiveness/ } \\
\text { daydreaming }\end{array}$ & & 12 \\
\hline $\begin{array}{l}\text { Being unmotivated and } \\
\text { showing a lack of } \\
\text { interest to study all the } \\
\text { time }\end{array}$ & & 12 \\
\hline $\begin{array}{l}\text { Manipulating/dominating } \\
\text { classmates }\end{array}$ & & 10 \\
\hline Playing in the class & & 07 \\
\hline Not doing homework & & 08 \\
\hline Copying homework & & 07 \\
\hline Copying exams & & 07 \\
\hline $\begin{array}{l}\text { Forget to bring textbooks } \\
\text { and other learning } \\
\text { materials to class }\end{array}$ & & 08 \\
\hline $\begin{array}{l}\text { Not responding to } \\
\text { teachers' questions at all } \\
\text { and stay silence } \\
\text { throughout the lesson }\end{array}$ & & 06 \\
\hline
\end{tabular}

\subsubsection{Categories of school-based student misbehaviors}

The responses on the types of student school-based misbehaviors were classified into 07 main categories, and 04 of them were further divided into subcategories. As presented in Table 02, the highly reported categories of school-based student misbehaviors were: "disrespecting school authority figures (school principal, teachers and prefects)", "unnecessary involvement with dangerous drugs", "developing and supporting inappropriate relationships which are not suitable to students" age and harmful for them", "not following school rules" and "destroying school property".

All the participants said that it is truly hard to manage student misbehavior in schools, because nowadays most of the students disrespect school authority figures. For example, Participant 08 mentioned,

"Unlike past, present students do not respect even the school principal. It is very hard to manage schools. 10-15 years ago, we saw students who not only respected teachers but also school prefects. They did not bring any unnecessary stuff to the school due to the fear of school prefects. But now, even most of the prefects are misbehaving. It is very difficult for us to appoint school prefects."

The second highly influential school-based student misbehavior is some students' unnecessary involvement with dangerous drugs such as Ganja, Cocaine, and Marijuana. The majority of participants explained that they have found some students consuming and distributing drugs even in the school premise, especially Thule. This is 
one of the main problems in all the schools currently.

Furthermore, according to the participants, most of the secondary school students develop and support inappropriate relationships that are not suitable for their age and harmful for them. Among them, developing romantic heterosexual relationships is very common. They mentioned most of these relationships are misleading and harmful to the students' development because they make these relationships just to have fun by seeing their peers having partners and without having a proper understanding of what they do. Then, they do not prioritize on their studies. Except one or two, all these romantic relationships are temporary and based on physical attraction. In addition, four participants mentioned that they found some homosexual issues among students in their schools.

The next highly reported categories of school-based student misbehavior were " not following school rules" and "destroying school property". Under the category of "not following school rules", all the participants mentioned most of the students do not wear the school uniform as it should be worn.

Participant 07 - "They make their uniforms fashionable in numerous ways. Some girls' frocks are very short and some boys' trousers are very tight in the upper part and wearing them below to the waist. Also, some boys come to school with inappropriate hairstyles. Even though, we advise them and give punishments, some of the students do the same"

Only two teachers reported late attendance of students to school. A majority of participants stated nowadays most of the students do not protect school property well. They destroy school property by breaking furniture, water pipes and door locks and writing inappropriate stuff (drawing naked pictures, writing songs) on walls and desks.

Table 2: A summary of the perceptions of school-based student misbehaviors

\begin{tabular}{|c|c|c|}
\hline Category & Subcategory & $\begin{array}{l}\text { Number of } \\
\text { responses }\end{array}$ \\
\hline \multirow[t]{3}{*}{ Disrespecting school authority figures } & Disrespecting school principal and teachers & 12 \\
\hline & Ignoring/ cheating/ not listening to school prefects & 12 \\
\hline & Subtotal & 24 \\
\hline \multirow{3}{*}{$\begin{array}{l}\text { Unnecessary involvement with } \\
\text { dangerous drugs }\end{array}$} & Experimenting drugs & 12 \\
\hline & Distributing drugs & 10 \\
\hline & Subtotal & 22 \\
\hline \multirow{3}{*}{$\begin{array}{l}\text { Developing and supporting } \\
\text { inappropriate relationships which are not } \\
\text { suitable to students' age and harmful for } \\
\text { them }\end{array}$} & Romantic heterosexual relationships & 12 \\
\hline & Homosexual relationships & 06 \\
\hline & Subtotal & 18 \\
\hline \multirow[t]{3}{*}{ Not following school rules } & Not wearing school uniform properly & 12 \\
\hline & Late attendance to the school & 03 \\
\hline & Subtotal & 15 \\
\hline Destroying school property & & 10 \\
\hline $\begin{array}{l}\text { Distributing inappropriate movie CDs } \\
\text { and such related unsuitable materials } \\
\text { among school mates. }\end{array}$ & & 07 \\
\hline Drinking Alcohol & & 06 \\
\hline
\end{tabular}

\subsection{Reasons for Student Misbehavior}

The participants pointed out many reasons to above mentioned student misbehaviors. According to the perceptions of the participants, the reasons behind student misbehavior were simplified to five main sources: family, education system, teachers, students and society.

4.3.1. Family

All the participants mentioned that family background highly influences students' behavior. The students who do not receive sufficient attention, love and care from home tend to misbehave more in the school. Especially, the students who are not living with parents, living with a divorced or problematic family environment are easily involved with problematic behaviors. In addition, the majority of participants highlighted that most of the misbehaving students' parents do not attend the parents' meetings in school. Even though teachers attempt to contact them personally to get their support to improve the student's behavior, some parents even do not respond to those messages. In addition, according to the participants, there is another group of parents, they do not believe at all that their child is misbehaving in school and they just blame the teachers thinking that the teachers are lying. Because of these reasons, participants mentioned that currently teachers do not receive sufficient support from the families of most of the misbehaving students to improve their behavior. Therefore, these 
students tend to continue their misbehaviors.

4.3.2. Education System

All the participants pointed out some issues with the current Sri Lankan education system that are highly influencing to escalate student misbehaviors in schools. They are: overloaded and highly knowledge based curriculums (less focused on life skills development), overcrowded classrooms and written exam based evaluation method.

They mentioned that they do not have sufficient time to focus on each child's issues in the classroom as a result of teaching fast to cover the large syllabus they are required to complete no matter what. Under this situation, not only students but also teachers are experiencing so much stress every day and have less free time to engage in play and other relaxing activities with students. According to the participants, most of the students attempt to get rid of their distress temporally by misbehaving in the school. Furthermore, all the participants highly emphasized our current education system does not improve students' life skills, morals and their human qualities such as empathy, helpfulness, kindness, compassion and highly focus on preparing students to write exams. Therefore, students have become very selfish and machinery type individuals whose only goal is to pass the exams somehow.

Participant 8-"In the past, we studied subjects like community studies and social studies. Students could develop their spirit and human qualities through those subjects, but, nowadays, we don't have such subjects. Students are encouraged to study demanding subjects focusing on the job market. So, they do not learn good morals and values and easily involve inappropriate things."

Furthermore, all the participants stressed that students vastly learn and practice more problematic behaviors by attending to private tuition classes, because, they experience more freedom to use mobile phones, do fashions and do anything that they want there due to not having any restrictions. Consequently, students expect to have the same atmosphere in the school and try to engage in inappropriate behaviors. In addition, they mentioned students have less motivation to study in schools by having an opportunity to learn the same lesson in private tuition classes. Since the education is free in government schools, most of the students do not value learning at school like having private tuition classes. Therefore, they tend to misbehave after coming to school.

4.3.3 Teachers

The whole sample group pointed out the teacher's personality, the way he/she communicates with students, and his/her teaching methods highly affect students' misbehaviors. Furthermore, the majority mentioned if a student misbehaves in front of the teacher, then it is a weakness of the teacher.

Participant 09- "Teacher's level of preparation to the lesson and the teaching style is very important to get the attention of students. If students identify the teacher cannot teach properly, then they do not listen to that teacher and even tend to make fun out of the teacher. The teacher must have good teaching and leadership skills"

Furthermore, they highlighted that teachers' ineffective student behavior management strategies can increase students' misbehavior. For example, highly criticizing or punishing disobedient students in public and spreading only negative remarks of the student in the school.

4.3.4. Students

All the participants mentioned that the most of students in the present society are selfish. They interrupt others profusely by misbehaving during the lesson since they do not think that much about others. In addition, six participants mentioned that present students highly expect love and friendliness from teachers compared to their past students (the students whom they taught 10-15 years ago). If the teacher is not friendly, then the students will ignore him/her and misbehave in the classroom.

4.3.5. Society

According to all the teachers, students learn most of their problematic behavior through social media, the internet, television and using mobile phones. Students highly observe aggressive, violent behavior and other ageirrelevant matters through the internet, social media, teledrama, movies and cartoons. In addition, they stressed that present society is not safe for school students and they are always in a huge danger to get involved with unnecessary groups/gangs who involve in criminal acts, delivering and consuming dangerous drugs and experimenting sexual behaviors.

\section{Discussion}

The findings of the research study revealed that compared to the students that the teachers have taught and been with 10-15 years ago, secondary school students they currently teach, do not respect teachers, show more selfcentered behaviors and engage in more problematic behaviors in school which are harmful to themselves as well as to the others.

According to the United Nations Convention on the Rights of the Child (2001), the education of children must be focused on "the development of the child's personality, talents, mental and physical abilities to their fullest potential; the development of respect for human rights and fundamental freedoms, and for the principles enshrined in the Charter of the United Nations; the development of respect for the child's parents, his or her own 
cultural identity, language and values, for the national values of the country in which the child is living, the country from which he or she may originate, and for civilizations different from his or her own; the preparation of the child for responsible life in a free society, in the spirit of understanding, peace, tolerance, equality of sexes, and friendship among all peoples, ethnic, national and religious groups and persons of indigenous origin and the development of respect for the natural environment."(p.1) When analyzing the findings of this research study, especially the participants' views on the reasons behind the negative behavioral changes among Sri Lankan secondary school students, it emphasizes the need of questioning whether the Sri Lankan education system is currently achieving all above mentioned goals of education.

Not only this study but also many previous studies have revealed that a majority of Sri Lankans believe that the country's current education system is not effective for students due to overloaded school curriculums and tough competitive examinations as the students have less time to engage in extra-curricular activities. In addition, these studies have further elucidated that teachers do not use modern and innovative teaching strategies and flexible assessment systems, instead they still follow traditional examination system which requires only memorizing information. (e.g. Jayaweera,2010; Lekamge et.al,2008; McCaul,2007; Liyanage, 2014) Under these circumstances, it can be assumed that current schools highly promote a fearful, competitive and stressful atmosphere for students. Consequently, they may highly experience fear of failure, fear of humiliation and fear of disapproval. Therefore, students might attempt to cope with these anxieties, fears and stresses defensively by engaging in different types of misbehaviors or off-task behaviors in schools. Furthermore, it can be identified that this negative atmosphere eliminates students' intrinsic motivation and curiosity for learning and makes students afraid of taking opportunities and challenges that are essential to acquire true learning experiences. That is why the students misbehave and even interrupt the teacher and other students in the classroom during the lessons. If they learn with curiosity and intrinsic motivation, they would attempt to pay attention to their lessons and would study showing the qualities of grit and perseverance. It seems that most of these misbehaving students study with the intention of obtaining good grades just to avoid embarrassment of falling exams and to avoid disapproval from others, especially from parents.

In order to reduce and prevent these negative behavioral issues, it is obvious that making some changes in the current education system is highly needed. So that, current overloaded school curriculums and inflexible traditional examination procedures which highly promote rote memorization and competition must be removed. It is crucial to develop new school curriculums which can change the stressful atmosphere in schools and successfully promote students' physical, cognitive, personal, social, emotional and spiritual development. School curriculums must not only focus on developing academic and professional knowledge and skills among students, but also developing life skills, soft skills and human qualities among students such as empathy, loving-kindness, sharing, caring, honesty, cooperativeness, courage and altruism. The findings of the study indicate that such skills and human qualities are less shown by present secondary school students. In addition, schools must be provided with sufficient facilities and teachers must be provided with proper training to teach subjects using practical and modern teaching strategies. Furthermore, school teachers and principals must be provided with proper trainings on student behavior management so that they can contribute effectively to reduce misbehaviors and promote positive behaviors among students.

Moreover, it is truly important to make the general public aware on the real purposes of education to change their narrow and self-centered views on learning and encourage them to learn not for the sake of achieving personal superiority by defeating others, but with the intention of becoming good human beings to serve this world. Especially, it is crucial to make aware parents on this so that they can effectively guide their children to become good human beings in the society by being proper role models to them.

One of the limitations of this study is that the research sample is not more representative. Therefore, in order to examine the applicability of these findings to other areas in the country and acquire an in-depth understanding on the misbehaviors of Sri Lankan students, it would be useful to carry out a quantitative research study covering the whole country. In addition, it would be worthwhile to conduct research studies with students and parents to identify their perceptions on student misbehaviors.

\section{References}

Aloe, A.M., Amo, L.C., \& Shanahan, M.E. (2014). Classroom management, self-efficacy and burnout: A multivariate meta-analysis. Educ Psychol Rev, 26, 101-126.

Austin, J.L., \& Agar, G.L. (2005) 'Helping young children follow their teachers' directions: The utility of highprobability command sequences in pre-k and kindergarten classrooms'. Education and Treatment of Children, 28 (3), 222-36.

Chang, M.L. (2013). Toward a theoretical model to understand teacher emotions and teacher burnout in the context of student misbehavior: appraisal, regulation, and coping. Motivation and Emotion.

Charles, C.M. (2008). Building classroom discipline (9 ed.). New York: Pearson Education, Inc.

Çimen,S.S., Çepik-Kiriş, H. (2015). Pre-service EFL teachers' perceptions of and strategies in dealing with 
misbehavior. International Journal of Educational Researchers, 6 (3), 43-49.

Clunies-Ross, P., Little, E., and Kienhuis, M. (2008). Self-reported and actual use of proactive and reactive classroom management strategies and their relationship with teacher stress and student behavior. Educational Psychology, 28 (6), 693-710.

Crawshaw, M. (2015). Secondary school teachers' perceptions of student misbehaviour: A review of international research, 1983 to 2013. Australian Journal of Education, 59(3), 293-311.

Dalgıç, G., \& Bayhan, G. (2014). A Meta-analysis: Student misbehaviors that affect classroom management. Cypriot Journal of Educational Sciences. 9(2), 101-116.

Ding, M., Li, Y., Li, X. \& Kulm, G. (2008). Chinese teachers' perceptions of students' classroom misbehavior. Educational Psychology, 28(3), 305-324.

Finn, J.D., Fish, R.M., \& Scott, L.A. (2008). Educational sequelae of high school misbehavior. The Journal of Educational Research, 101(5), 259-274.

Gregg, J. (1995). Discipline, control, and the school mathematics tradition. Teaching and Teacher Education, 11(6), 579-593.

Hwung, A. (2016). "Peer misbehavior effects in the classroom". CMC Senior Theses. Paper 1345. http://scholarship.claremont.edu/cmc_theses/1345

Jayaweera, S. (2010). A study on the current school curriculum and its contribution towards the achievement of national goals and basic competencies identified by the national education commission, Vol.1, Colombo: Sri Lanka Association for the Advancement of Education, National Education Commission and Asian Development Bank.

Kathryn L. (2010). "Teachers' Perceptions of Classroom Management Factors that Contribute to Stress and Likeliness to Seek Consultation from School Counselors". Counselor Education Master's Theses. 35. http://digitalcommons.brockport.edu/edc_theses/35

Koutrouba, K. (2013). Student misbehaviour in secondary education: Greek teachers' views and attitudes. Educational Review, 65(1), 1-19.

Kyriacou, C, Ortega, J.L, (2010). Beginning secondary school teachers' perceptions of pupil misbehavior in Spain. Teacher development, 14(4), 415-426.

Lekamge, D., Gunawardana, C., Karunanayake, S., De Zoysa,S. (2008). A study on instructional strategies used by teachers for development of hoer order cognitive skills in students, Faculty of Education, Open University of Sri Lanka, Sri Lanka.

Liyanage, I.M. (2014). Education System of Sri Lanka: Strengths and Weaknesses.

Little, E, 2005. Secondary school teachers' perceptions of students' problem behaviors. Educational Psychology, 25(4), 369-377.

Mahasneh, A, Nor, S, Aroff, A, Abdullah, N, Samah, B, Mahasneh, A,Asiri,M. (2012). Misbehaviour in Jordanian secondary schools. Asian social science, 8 (6), 121-131.

Malak, S., Deppeler, J. M., \& Sharma, U. (2014). Bangladeshi teachers' perceptions about student behaviour in primary schools. International Journal on School Disaffection, 11(1), 59-78.

McCaul, T. (2007). Study of the implementation of Mathematics and Science curriculums in grades 6 and 10. World Bank: Colombo.

Mohammad,A., Alireza,M., Hasan, T.(2013). On the secondary school teachers' perceptions of students' misbehavior: The case of Iranian male and female teachers. International Journal of Psychology and Behavioral Research. 2. 240-249.

Rieg, S.A., Paquette, K.R., and Chen, Y. (2007). Coping with stress: An investigation of novice teachers' stressors in the elementary classroom. Education, 128 (2), 211-17.

Sun, R.C.F., and Shek, D.T.L. (2012). 'Student classroom misbehavior: An exploratory study based on teachers' perceptions'. The Scientific World Journal. Online. www.hindawi.com/journals/tswj/2012/208907/.

Turnuklu, A., \& Galton, M. (2001). Students' misbehaviours in Turkish and English primary classrooms. Educational Studies, 27(3), 291-305.

Thomson, B. (2009). Disruptive behaviors in Barbarian classrooms: Implications for universal secondary education in the Caribbean. Journal of Eastern Caribbean Studies, 34(3), 39-58.

Tsouloupas, C.N., Carson, R.L., \& MacGregor, S.K. (2014). The development of high school teachers' efficacy in handling student misbehavior (TEHSM). The Journal of Educational Research, 107(3), 230-240

UN Committee on the Rights of the Child (CRC), General comment No. 1 (2001), Article 29 (1), The aims of education, 17 April 2001, CRC/GC/2001/1, available at: https:/www.refworld.org/docid/4538834d2.html.

Whisman, A. \& Hammer, P. C. (2014). The association between school discipline and mathematics performance: A case for positive discipline approaches. Charleston, WV: West Virginia Department of Education, Division of Teaching and Learning, Office of Research.

Willert, T. (2017, November 5). Survey: Student discipline monopolizes teachers' time. Retrieved from https://www.seattletimes.com/nation-world/survey-student-discipline-monopolizes-teachers-time/ 
Wilson, D. B., Gottfredson, D. C., \& Najaka, S. S. (2001). School-based prevention of problem behaviors: A Meta-analysis. Journal of Quantitative Criminology, 17(3), 247-272.

Yuan, X., \& Che, L. (2012). How to deal with student misbehaviour in the classroom? Journal of Educational and Developmental Psychology, 2(1),143-150.

Zoysa, P. D., Senarath, U., \& Silva, H. D. (2018). Disciplining in Sri Lankan schools: A cross-sectional Study. Journal of Interpersonal Violence, 088626051880885. 